\title{
Model simulations of the modulating effect of the snow cover in a rain-on-snow event
}

\author{
N. Wever ${ }^{1,2}$, T. Jonas ${ }^{1}$, C. Fierz ${ }^{1}$, and M. Lehning ${ }^{1,2}$ \\ ${ }^{1}$ WSL Institute for Snow and Avalanche Research SLF, Flüelastrasse 11, 7260 Davos Dorf, Switzerland \\ ${ }^{2}$ CRYOS, School of Architecture, Civil and Environmental Engineering, EPFL, Lausanne, Switzerland \\ Correspondence to: N. Wever (wever@slf.ch)
}

Received: 5 March 2014 - Published in Hydrol. Earth Syst. Sci. Discuss.: 15 May 2014

Revised: 5 September 2014 - Accepted: 10 October 2014 - Published: 26 November 2014

\begin{abstract}
In October 2011, the Swiss Alps underwent a marked rain-on-snow (ROS) event when a large snowfall on 8 and 9 October was followed by intense rain on 10 October. This resulted in severe flooding in some parts of Switzerland. Model simulations were carried out for 14 meteorological stations in two affected regions of the Swiss Alps using the detailed physics-based snowpack model SNOWPACK. We also conducted an ensemble sensitivity study, in which repeated simulations for a specific station were done with meteorological forcing and rainfall from other stations. This allowed the quantification of the contribution of rainfall, snow melt and liquid water storage on generating snowpack runoff. In the simulations, the snowpack produced runoff about 4-6h after rainfall started, and total snowpack runoff became higher than total rainfall after about 11-13 $\mathrm{h}$. These values appeared to be strongly dependent on snow depth, rainfall and melt rates. Deeper snow covers had more storage potential and could absorb all rain and meltwater in the first hours, whereas the snowpack runoff from shallow snow covers reacts much more quickly. However, the simulated snowpack runoff rates exceeded the rainfall intensities in both snow depth classes. In addition to snow melt, the water released due to the reduction of liquid water storage contributed to excess snowpack runoff. This effect appears to be stronger for deeper snow covers and likely results from structural changes to the snowpack due to settling and wet snow metamorphism. These results are specifically valid for the point scale simulations performed in this study and for ROS events on relatively fresh snow.
\end{abstract}

\section{Introduction}

For mountain regions, the presence of a snow cover is an important factor in hydrological processes. One type of event that is still poorly understood is the behaviour of a snow cover during rainfall. These rain-on-snow (ROS) events are often accompanied by strong snow melt, due to high latent heat exchange and incoming long-wave radiation (ILWR) that reduces the radiative cooling of the snowpack (Marks et al., 2001; Mazurkiewicz et al., 2008). These effects increase the water available for outflow from the snowpack, which hereafter we will refer to as snowpack runoff. In this way, heavy precipitation can more easily lead to flooding events in mountainous terrain due to the additional snow melt (Pradhanang et al., 2013; Sui and Koehler, 2001). Furthermore, rainfall reduces snowpack stability, resulting in stronger wet snow avalanche activity (Conway and Raymond, 1993).

This study focuses on the dynamical snowpack behaviour during a ROS event in October 2011 in the Swiss Alps. The event is described in detail in Badoux et al. (2013). During 8 October 2011, the passage of a cold front brought significant snowfall amounts on the north side of the Swiss Alps at altitudes above $800 \mathrm{~m}$, accompanied by a strong drop in air temperature. During 9 October, the precipitation faded and cold weather remained. In the night of 9 to 10 October, the passage of a warm front brought new precipitation, mainly rain, this time accompanied by a strong increase in air temperature. The snowfall limit finally increased up to $3000 \mathrm{~m}$ on 10 October. This ROS event is very suitable for a case study, because it occurred on a large scale and is well captured at many measurement sites. Furthermore, the fact that it caused widespread flooding shows that the event was ex- 
treme. One region, where the snow cover was relatively shallow, was more strongly affected by flooding than a region with a deep snow cover at the onset of rain (Badoux et al., 2013). An important question that arose from the event is whether there is a difference in snowpack behaviour for a shallow and a deep snow cover that may explain the difference in hydrological response in those two areas. The differences in streamflow response (Badoux et al., 2013), in terms of return period, would suggest that deep snowpacks can better dampen peak outflows than shallow ones.

Studies modelling ROS events mostly analyse the daily to weekly timescales and successfully reproduce the temporal evolution of snow water equivalent over several days (Marks et al., 1998, 2001). This suggests that snowpack-related processes during ROS events are sufficiently understood. Consequently, one can estimate rather precisely how much water will be available for snowpack runoff (Marks et al., 1998; Mazurkiewicz et al., 2008), but the temporal dynamics of the release of meltwater on the sub-daily timescales has seldom been investigated in detail. This knowledge is essential, however, to estimate the response in streamflow discharge in catchments and to assess flood risks from ROS events. In Rössler et al. (2014), the meteorological circumstances leading to this event have been studied in combination with a hydrological catchment scale model to simulate streamflow discharge in one of the affected areas. To reproduce the rapid peak discharge in the event, considerable recalibration of the hydrological model setup was required. For example, relatively simple single layer snow models, which are often used in hydrological model frameworks, were unable to follow the snow cover dynamics without significant calibration of snow-related parameters for this particular situation (Rössler et al., 2014).

The exact behaviour of the snow cover during ROS events is governed by complex interactions between several processes. A cold snow cover can store rain water by capillary suction and, to a lesser extent, freezing the liquid water. These processes depend on the state of the snow cover before the onset of rain. As soon as the snow cover becomes wet, strong settling has been observed (Marshall et al., 1999). This settling, combined with a destruction of the snow matrix by melt, reduces the storage capacity, which may increase snowpack runoff. These counteracting processes are difficult to assess without the use of a physics-based snow cover model that includes a representation of the above processes. Here, the detailed multi-layer snow cover model SNOWPACK (Lehning et al., 2002a, b) is used. The SNOWPACK model has been extended recently with a solver for the Richards equation, which provides a demonstrable improvement in modelling liquid water flow through the snow cover, especially on the sub-daily timescale (Wever et al., 2014). This study aims to simulate the snow cover dynamics at individual snow stations during this event, to better understand the snowpack behaviour with respect to the production of snowpack runoff.

\section{Methods and data}

The results in this study are achieved by simulations with the SNOWPACK model, using measurements from automated meteorological stations in the affected areas. First, the SNOWPACK model will be discussed, focusing in particular on the treatment of snow melt and liquid water flow in the model. Then the available data sets are discussed, followed by how the SNOWPACK model was set up to simulate the event using the measured meteorological data. Finally, we discuss the methods used for carrying out an ensemble sensitivity analysis and subsequent regression analysis to better understand the dynamics of snowpacks in this ROS event as simulated by the model.

\subsection{SNOWPACK model}

The physics-based snowpack model SNOWPACK was used to simulate the development of the snow cover as a $1 \mathrm{D}$ column, forced with the meteorological conditions as measured by meteorological stations. The model simulates snow cover development, e.g. temperature and density profiles, phase changes, microstructural parameters, liquid water infiltration and snowpack runoff (Lehning et al., 2002a, b). The simulations were done using SNOWPACK version 3.2.0 in which the solver for the Richards equation was introduced (Wever et al., 2014). Furthermore, improvements were made in the treatment of the boundary conditions for the energy balance and accompanying phase changes, which may explain some discrepancies with model results presented in Badoux et al. (2013).

Snow melt is an important source of liquid water in the snowpack. In the SNOWPACK model, snow melt occurs at a specific depth when the local temperature is $0{ }^{\circ} \mathrm{C}$ and excess energy is added at this depth either by heat conduction in the snow matrix or by a divergent short-wave radiation flux penetrating the snow. At the top of the snowpack, the model prescribes the energy flux as a Neumann boundary condition in the case of melting conditions in the top snow element or else as a Dirichlet boundary condition, prescribing the measured snow surface temperature. The latter ensures a better assessment of the cold content of the snowpack, although it may result in small discrepancies between changes in internal energy and the diagnosed energy balance. Prescribing the upper or lower boundary temperature may result in changes in internal energy between time steps that are not accounted for by the diagnosed top and bottom energy flux from the preceding time step.

The heat flux that is used to force the model at the top of the snowpack can be expressed as (Lehning et al., 2002a):

$Q_{\text {sum }}=Q_{\mathrm{LWnet}}+Q_{\mathrm{S}}+Q_{\mathrm{L}}+Q_{\mathrm{P}}$,

where $Q_{\text {sum }}$ is the prescribed flux $\left(\mathrm{W} \mathrm{m}^{-2}\right)$ for the Neumann boundary condition at the upper boundary, $Q_{\text {LWnet }}$ is the net long-wave radiation $\left(\mathrm{W} \mathrm{m}^{-2}\right), Q_{\mathrm{S}}$ is the sensible heat 
( $\left.\mathrm{W} \mathrm{m}^{-2}\right), Q_{\mathrm{L}}$ is the latent heat $\left(\mathrm{W} \mathrm{m}^{-2}\right)$ and $Q_{\mathrm{P}}$ is the heat advection by liquid precipitation $\left(\mathrm{W} \mathrm{m}^{-2}\right)$. The net shortwave radiation absorbed by the snowpack is not incorporated in the Neumann boundary condition for the temperature equation, as it is modelled as a source term in the top layers of the snowpack to reflect the penetration of short-wave radiation in the snowpack.

Water transport in snow is governed by capillary suction and gravitational drainage (Marsh, 2006). Two common model approaches for liquid water flow in snow are the socalled bucket scheme and Richards equation (Wever et al., 2014). In the bucket scheme, downward water transport is determined by the presence of an excess liquid water content above a defined threshold water content in a specific layer. This excess water is transported downwards regardless of the storage capacity of lower layers. In the Richards equation, the balance between gravity and capillary suction is explicitly calculated. It yields performance improvement over the bucket approach on both daily and hourly timescales (Wever et al., 2014). However, solving the Richards equation may be expected to especially improve the simulation of water flow in seasonal snow covers, where snow stratigraphy can have a marked influence on the water flow. Differences in grain sizes can lead to capillary barriers and ice lenses may block the water flow, resulting in ponding (Marsh, 1999; Hirashima et al., 2010). For this ROS event, the snow cover built up in two days, leading to a very homogeneous stratification.

The hydraulic properties of the snowpack, as used for solving the Richards equation, are expected to have changed as follows due to the wet snow metamorphism of the initially fresh, dry snow:

- Fresh, dry snow has generally a dendritic structure and thereby a high capillary suction. Old and wet snow on the other hand has coarse, rounded grains accompanied by lower capillary suction. In the water retention curve proposed by Yamaguchi et al. (2010), dendricity is not explicitly taken into account. However, SNOWPACK initialises new snow layers with small grains and these layers thereby exhibit also higher suction than melt forms or old snow in the simulations.

- The saturated hydraulic conductivity increases with grain size, but decreases with density. In wet snow metamorphism, both grain growth and densification are occurring. However, in the simulations in this study, saturated hydraulic conductivity following Calonne et al. (2012) was increasing during the event (not shown).

- Snow melt destroys the ice matrix locally and in wet snow, also settling and densification occur. When the matrix to store water is decreasing in volume due to snow melt and/or settling, this leads to a decrease in storage capacity and is expected to cause additional snowpack runoff.

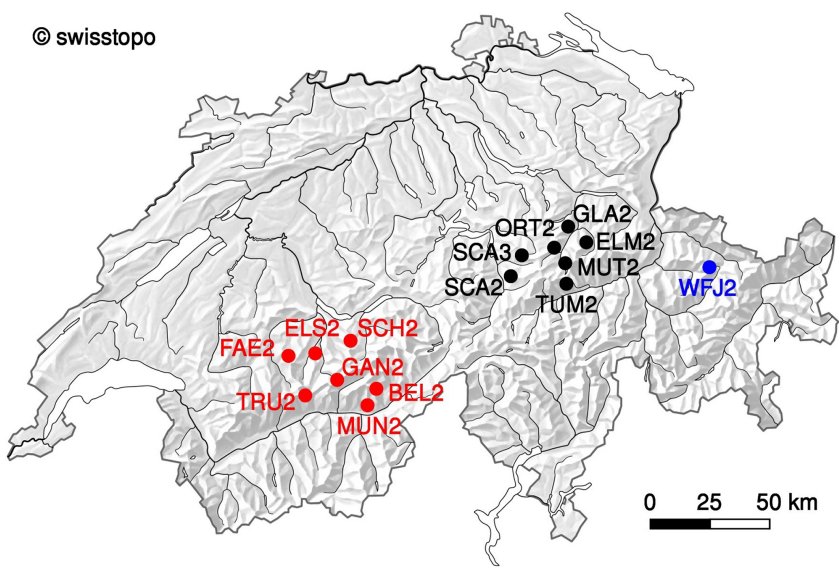

Figure 1. Map of Switzerland showing the locations of the stations used in this study in Bernese Oberland (red), Glarner Alpen (black) and the verification station Weissfluhjoch (blue). Reproduced by permission of swisstopo (JA100118).

\subsection{Data}

The behaviour of the snow cover during this ROS event is studied for two parts of the Swiss Alps: the Bernese Oberland and Glarner Alpen (Fig. 1). These areas were chosen because in particular the Bernese Oberland and to a lesser extent the Glarner Alpen experienced serious flooding (Badoux et al., 2013). The studied areas are both about $1000 \mathrm{~km}^{2}$. Both areas are located on the north side of the Alps and extend more or less over a similar altitude range, with glaciated areas in the highest parts. They are about $100 \mathrm{~km}$ apart, and, as will be shown, have experienced different meteorological forcing conditions.

In both areas, several automated weather stations are operated in the IMIS network. The stations measure meteorological and snow cover conditions at $0.5 \mathrm{~h}$ resolution. They are equipped with wind speed and direction, temperature, relative humidity, surface temperature, soil temperature, reflected short-wave radiation and snow height sensors. The stations are also equipped with an unheated rain gauge, which makes the precipitation measurements at the stations unreliable in case of snowfall and mixed precipitation. In both the Bernese Oberland and Glarner Alpen, seven stations were selected for this study (14 in total), as shown in Fig. 1 and listed in Table 1. These particular stations were selected because they represent the altitudinal gradient in the two regions and had limited missing values during the event. The sites are located in relatively flat terrain. The data have been quality checked manually and missing values were interpolated from neighbouring stations (Badoux et al., 2013). Most corrections were needed for wind speed, as the relatively wet snow caused the wind speed sensor to freeze at some stations. For interpreting the results, it is important to note that the average altitude of the analysed stations in the Glarner Alpen is about $270 \mathrm{~m}$ lower than in the Bernese Oberland. 
Table 1. List of station abbreviations, station names, station altitudes and statistics for the two study areas and the verification station. The statistics denoted with Event are determined over the period 9 October, 18:00 UTC-11 October, 00:00 UTC. The bracketed sign before the root mean square error (RMSE) of snow height denotes whether modelled snow height is on average higher $(+)$ or lower $(-)$ than measured snow height. Time lag is the lag between the start of rain and the start of snowpack runoff and time runoff $>$ rain denotes the time it took before cumulative snowpack runoff exceeded cumulative rainfall; w.e., water equivalent.

\begin{tabular}{|c|c|c|c|c|c|c|c|c|c|c|c|}
\hline Stn & Name & $\begin{array}{l}\text { Altitude } \\
\text { (m) }\end{array}$ & $\begin{array}{c}\text { Max } \\
\text { snow height } \\
\text { 6-14 Oct } \\
(\mathrm{cm})\end{array}$ & $\begin{array}{c}\text { RMSE } \\
\text { snow height } \\
\text { Event } \\
(\mathrm{cm})\end{array}$ & $\begin{array}{l}\text { Rainfall } \\
\text { Event } \\
(\mathrm{mm})\end{array}$ & $\begin{array}{c}\text { Deposition } \\
\text { Event } \\
\text { (mm w.e.) }\end{array}$ & $\begin{array}{l}\text { Snow melt } \\
\text { Event } \\
\text { (mm w.e.) }\end{array}$ & $\begin{array}{l}\text { Snowpack } \\
\text { runoff } \\
\text { Event } \\
\text { (mm w.e.) }\end{array}$ & $\begin{array}{c}\text { Cold } \\
\text { content } \\
\left(\mathrm{kJ} \mathrm{m}^{-3}\right)\end{array}$ & $\begin{array}{l}\text { Time lag } \\
\text { (h) }\end{array}$ & $\begin{array}{c}\text { Time } \\
\text { runoff }>\text { rain } \\
\text { (h) }\end{array}$ \\
\hline \multicolumn{12}{|c|}{ Bernese Oberland } \\
\hline FAE2 & Faermel & 1970 & 39 & $(+) 4.6$ & 63 & 1.0 & 29 & 97 & 6 & 1.8 & 4.8 \\
\hline ELS2 & Elsige & 2140 & 44 & $(+) 2.4$ & 59 & 1.3 & 34 & 94 & 33 & 3.5 & 6.2 \\
\hline MUN2 & Mund & 2210 & 53 & $(+) 3.4$ & 34 & 2.3 & 45 & 78 & 94 & 3.0 & 7.0 \\
\hline $\mathrm{SCH} 2$ & Schilthorn & 2360 & 70 & $(-) 4.0$ & 88 & 0.5 & 14 & 95 & 387 & 4.8 & 19.5 \\
\hline TRU2 & Trubelboden & 2480 & 37 & (+) 3.7 & 84 & 0.8 & 22 & 106 & 68 & 3.8 & 9.8 \\
\hline BEL2 & Belalp & 2556 & 51 & $(+) 6.5$ & 43 & 0.2 & 5 & 44 & 166 & 2.8 & 18.8 \\
\hline GAN2 & Gandegg & 2717 & 103 & $(+) 18.4$ & 75 & 0.4 & 2 & 63 & 1265 & 10.0 & - \\
\hline \multicolumn{2}{|c|}{ Average all } & 2348 & 57 & $(+) 6.1$ & 64 & 0.9 & 21 & 82 & 288 & 4.2 & 11.0 \\
\hline \multicolumn{12}{|c|}{ Glarner Alpen } \\
\hline GLA2 & Glaernisch & 1630 & 99 & (+) 4.4 & 72 & 0.7 & 36 & 97 & 294 & 7.5 & 14.5 \\
\hline ORT2 & Ortstock & 1830 & 108 & $(-) 4.2$ & 76 & 3.8 & 70 & 142 & 798 & 7.5 & 12.5 \\
\hline $\mathrm{SCA} 2$ & Schächental & 2030 & 73 & $(-) 6.4$ & 75 & 2.5 & 71 & 146 & 330 & 5.5 & 9.8 \\
\hline ELM2 & Elm & 2050 & 90 & $(-) 3.1$ & 53 & 1.0 & 24 & 67 & 559 & 5.2 & 13.0 \\
\hline TUM2 & Tumpiv & 2195 & 93 & (-) 2.0 & 41 & 0.6 & 33 & 67 & 662 & 5.0 & 10.8 \\
\hline SCA3 & Schächental & 2330 & 90 & $(-) 7.1$ & 81 & 1.6 & 23 & 95 & 972 & 5.2 & 14.8 \\
\hline MUT2 & Muttsee & 2474 & 92 & $(-) 4.8$ & 63 & 0.7 & 10 & 61 & 932 & 7.0 & - \\
\hline \multicolumn{2}{|c|}{ Average all } & 2077 & 92 & $(-) 4.6$ & 66 & 1.5 & 38 & 96 & 649 & 6.1 & 12.5 \\
\hline \multicolumn{12}{|c|}{ Verification station } \\
\hline WFJ & Weissfluhjoch & 2540 & 48 & $(+) 2.4$ & 33 & 1.1 & 18 & 47 & 799 & 4.8 & 11.2 \\
\hline
\end{tabular}

For this study, the model was forced to interpret increases in measured snow height at the IMIS stations as snowfall (following Lehning et al., 1999), deriving the new snow density from a parameterised relationship with wind speed, temperature and relative humidity (Schmucki et al., 2014). The unheated rain gauges at the IMIS stations are not useful during these types of events, so to estimate rainfall, a different approach was followed. The Swiss Federal Office of Meteorology and Climatology (MeteoSwiss) is operating weather stations with a heated rain gauge (SwissMetNet stations). Combined with several totalisers for precipitation, which are read off once per day, these precipitation measurements are compiled in a gridded data set (RhiresD, MeteoSwiss, 2013) at $2 \mathrm{~km}$ resolution with daily precipitation sums (06:00-06:00 UTC). To estimate the liquid precipitation input at an IMIS station, the daily sum derived from the nine grid points closest to the IMIS station in the RhiresD gridded data was distributed over the day by using the relative amounts of precipitation registered by the closest SwissMetNet station. The rainfall started after 18:00 UTC on 9 October and consequently, all precipitation values before this time are set to zero, as snowfall is determined separately from the snow height measurements.

To validate the model performance for the chosen methods and data preparation procedures, data from the experimental site Weissfluhjoch (WFJ), located at $2540 \mathrm{~m}$ altitude in east
Switzerland near Davos (Fig. 1), were also used in this study. The course of the ROS event at this measurement site was quite similar to the 14 chosen IMIS stations, although both snowfall and rainfall amounts were smaller. At WFJ, both incoming and outgoing long- and short-wave radiation are available in addition to the default IMIS-type station setup, enabling a full assessment of the surface energy balance (abbreviated below as full EB). Furthermore, the site is equipped with a heated rain gauge that is part of the SwissMetNet network and a snow lysimeter that measures snowpack runoff (Wever et al., 2014), enabling the validation of simulated snowpack runoff.

\subsection{Model setup}

The model was initialised with 10 soil layers of $1 \mathrm{~cm}$ each. This allows the measured soil temperature at the lower boundary to be prescribed and, thereby, an estimate of the soil heat flux to be achieved. To allow for a spin-up period, the model simulations were started at 2 September, 6 weeks before the event. We consider this to be sufficient time for a soil of $10 \mathrm{~cm}$ depth. For soil parameters, typical values for very coarse material were chosen (similar to Wever et al., 2014). Furthermore, a free drainage lower boundary condition was used. This combination prevents liquid water ponding in the soil or snow. We hypothesise that this is generally 
not happening in the sloped terrain in the Swiss Alps, where liquid water that cannot directly infiltrate the soil is expected to leave the snowpack downslope, instead of ponding inside the snowpack.

A temperature threshold of $0.0{ }^{\circ} \mathrm{C}$ is used to determine whether precipitation should be considered rain (from RhiresD) or snow (from the snow height sensors). This threshold is determined by comparing the ventilated and unventilated temperature sensor at WFJ during this particular event. It was found that during the onset of rain, the ventilated sensor was close to $1.2^{\circ} \mathrm{C}$ when the unventilated IMIS type sensor was measuring around $0.0^{\circ} \mathrm{C}$. This discrepancy may have arisen from bad ventilation due to wet snow collected onto the sensor hut, or condensation from the moist air on the temperature sensor itself. Because the onset of rain was accompanied by a strong and quick increase in air temperature, the influence of the choice of threshold on the results is small. In the case of snowfall, a snow element is added to the model domain for each $2 \mathrm{~cm}$ of new snow. In the case of rainfall, the water flux is either added to the top element (bucket scheme) or applied as a Neumann boundary condition (Richards equation).

For calculating the heat fluxes in Eq. (1), a neutral atmospheric stratification was assumed, which is likely an appropriate assumption because of the windy conditions during the event. The turbulent heat fluxes were calculated following a standard Monin-Obukhov parameterisation (Lehning et al., $2002 \mathrm{~b}$ ), using a roughness length $z_{0}$ of $0.002 \mathrm{~m}$. The net radiation is approximated by using the measured reflected shortwave radiation and a parameterised albedo (Schmucki et al., 2014). Because the IMIS stations do not measure ILWR, this was approximated by the Omstedt (1990) parameterisation, using an estimated cloud cover. Based on observations of cloudiness at the MeteoSwiss station at Jungfraujoch, cloudiness was set to 1.0 in the period from 7 October to 9 October, 10:00 UTC and from 9 October, 17:00 to 11 October, when there was either solid or liquid precipitation, and 0.5 (half cloudy) for all other times.

\subsection{Methods}

To investigate the factors influencing the response of the snow cover during the ROS event, we added a sensitivity study by also forcing the SNOWPACK model for each station with the meteorological conditions from all the other stations. Snow melt is mainly governed by atmospheric conditions (temperature, relative humidity and wind speed), whereas liquid precipitation causes relatively little melt. Therefore, we consider atmospheric conditions and liquid precipitation as independent forcings during the event and treat them separately. The meteorological forcing, excluding the liquid precipitation, at the 14 stations represents 14 different melt scenarios. For liquid precipitation, we also have 14 more or less unique scenarios, although the temporal distribution over the day is based on eight SwissMetNet stations only. However, the scenarios provide differences in rainfall amounts due to the spatial distribution as captured in the RhiresD data set by spatial interpolations and climatological lapse rates. So for each of the 14 stations, with its own unique maximum snow height, we performed an ensemble of 2744 simulations $(14 \times 14 \times 14)$ with the SNOWPACK model, with every combination of melt and liquid precipitation scenario for statistical analysis. By replacing time series at a measurement site with a time series from another site, self-consistent series with real meteorological conditions that occurred during the event were created to act on the snow cover existing at the site. The original meteorological measurements at each station were used to force the model up to the moment on which the rainfall started on 9 October. From this specific time onwards, the meteorological and precipitation forcing was replaced by forcings from other stations. The starting time for these replacement series was taken as the moment on which rainfall started at these other stations.

To analyse possible different effects on snowpack runoff for shallow and deep snow covers, the 14 IMIS stations were divided into a shallow and deep snow cover class, depending on being above or below the median of maximum snow height during the event. The stations in Bernese Oberland are all present in the shallow snow cover class, except for GAN2, and all stations in Glarner Alpen are in the deep snow cover class, except SCA2. Per class, we determined a best fit by the linear regression for a given cumulative period using all ensemble simulations in the respective class:

$Q_{\text {cum }}=\alpha P_{\text {cum }}+\beta M_{\text {cum }}+b$,

where $Q_{\text {cum }}$ is the cumulative snowpack runoff sum (mm w.e.), $P_{\text {cum }}$ is the cumulative precipitation sum $(\mathrm{mm})$, $\alpha$ is the linear regression coefficient for precipitation, $M_{\text {cum }}$ is the cumulative snow melt sum (mm w.e.), $\beta$ is the linear regression coefficient for snow melt and $b$ is the intercept. In this context, $b$ can be interpreted as the change in liquid water storage in the snow cover. As a positive value of $b$ describes the snowpack runoff in the absence of any rain or snow melt, it can be assumed to reflect the recession curve and the effect of a decreasing water holding capacity, for example due to snow settling, wet snow metamorphism or changing hydraulic conductivity.

The dependence of the fit coefficients $\alpha, \beta$ and $b$ over varying cumulative periods can reveal how the snow cover is modulating precipitation input and snow melt when generating snowpack runoff. These coefficients will be used on the original simulations to attribute the individual contributions of snow melt, precipitation and the intercept (change in storage) to the modelled snowpack runoff. The linear regression was done for cumulative periods of $0-1$ to $0-24 \mathrm{~h}$ with two approaches: (i) taking the onset of rain at the stations as the start of the cumulative period and (ii) taking the onset of snowpack runoff as the start of the cumulative period. The latter was determined by both an increase of snowpack runoff by a factor of 2 compared to the snowpack runoff at 


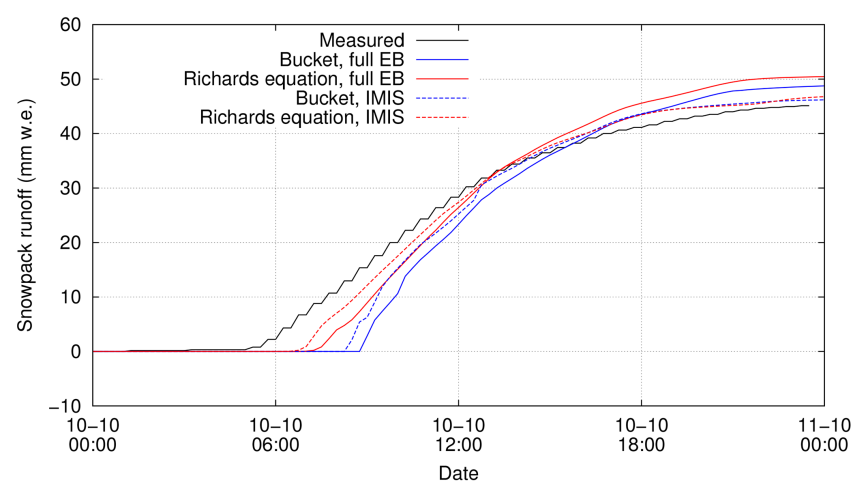

Figure 2. Comparison of modelled snowpack runoff using the bucket scheme or Richards equation for liquid water transport in the snowpack with measured snowpack runoff by a snow lysimeter for the station Weissfluhjoch, for 10 October. Simulations are done with either the full energy balance meteorological forcing (solid lines) or the forcing available for IMIS-type stations (dashed lines).

the onset of rain and a modelled snowpack runoff larger than $0.5 \mathrm{~mm}$ in $15 \mathrm{~min}$.

\section{Results}

\subsection{Verification}

Before discussing the simulations for the two study regions, the results for the verification station WFJ will be presented. Figure 2 shows the modelled and measured snowpack runoff at the WFJ for the ROS event, starting shortly before the onset of rain. The measured snowpack runoff started shortly after midnight on 10 October, although this involved only marginal amounts, most likely related to snow melt at the snowpack base due to the ground heat flux. The measured snowpack runoff strongly increased just before 06:00 UTC, which we associate with the arrival of the liquid water added to the snowpack by rainfall and snow melt near the snow surface. This particular moment is found 1.5 (for RE with IMIS type setup) to $3.5 \mathrm{~h}$ (for bucket with full EB type setup) later in the simulations. Here, the neglect of preferential flow in the model probably plays a role. There is strong observational evidence for preferential flow paths in snow that transport liquid water down efficiently (Kattelmann, 1985; Marsh, 2006; Katsushima et al., 2013), but currently, a modelling concept for this process is not available.

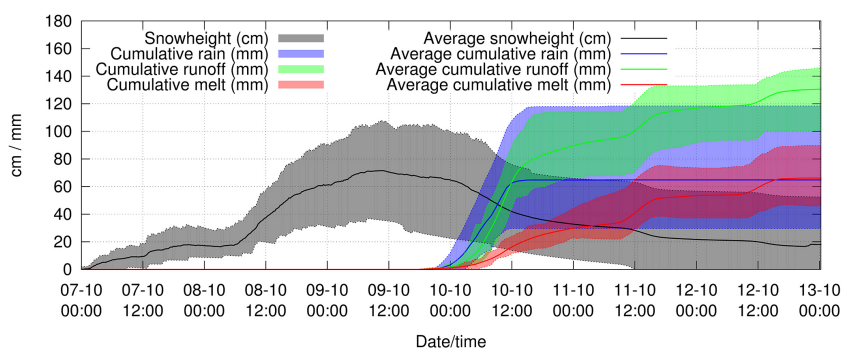

Figure 3. Overview of the simulation results of the temporal evolution of the ROS event between 7 and 13 October. Shown is the range of absolute minimum and maximum modelled snow height, cumulative precipitation, cumulative snowpack runoff and cumulative melt over the 14 stations. The solid lines denote the average values. The accumulation for precipitation and melt was calculated from 9 October, 18:00 UTC onwards.

Nevertheless, solving liquid water flow in the snow cover with the Richards equation is providing a closer agreement with observed snowpack runoff than with the bucket scheme concerning the timing of the start of snowpack runoff. Both models are overestimating the snowpack runoff rate, as shown by the steeper cumulative curve, although this overestimation is larger with the bucket scheme. In contrast, the total runoff sum at the end of the day is overestimated more in simulations with the Richards equation than with the bucket scheme. Because of the focus on snowpack runoff dynamics during the event in this study, we chose to do all further calculations with the Richards equation only. It should be noted, however, that several parameterisations are not yet verified with the Richards equation (metamorphism, snow settling, etc.).

In spite of some differences between the full energy balance station from WFJ and the IMIS-type setup from WFJ, it can be seen that the approach of parameterising ILWR and deriving precipitation from the RhiresD data and the SwissMetNet stations is providing reasonable results. It shows that the methods used in this study are suitable for analysing the dynamical snowpack behaviour at the IMIS stations in the two study areas. It should be noted, however, that the timing of precipitation for WFJ is very accurate, because a heated SwissMetNet rain gauge is located at this site, whereas for other stations, the closest SwissMetNet station is generally several kilometres away.

\subsection{Event description}

The event started with snowfall above $800 \mathrm{~m}$ altitude on 7 October. Figure 3 shows the temporal development of snow cover height in the two study regions. The snowfall was quite continuous and the maximum snow height averaged over all stations was reached around 9 October, 12:00 UTC. Table 1 shows that the average maximum snow height at the seven IMIS stations in Bernese Oberland was $57 \mathrm{~cm}$, less than the 
$92 \mathrm{~cm}$ in the Glarner Alpen. In Bernese Oberland, snowfall amounts tended to increase with altitude, whereas interestingly, this trend was absent in the Glarner Alpen.

After the maximum snow height was reached, the snow height started decreasing, although rain and surface snow melt had not started yet. This decrease can be attributed mainly to settling of the snowpack and melt at the snowpack base by the ground heat flux. The following precipitation event started after 18:00 UTC on 9 October, and consisted purely of rainfall (except for very high altitudes). It was accompanied by a rapid increase of the $0{ }^{\circ} \mathrm{C}$-isotherm to $3000 \mathrm{~m}$ altitude. The rainfall lasted until 15:00 UTC on 10 October, with an average rainfall sum of about $65 \mathrm{~mm}$ for both areas (Table 1). This gives a higher precipitation rate during the rainfall period than during the snowfall period.

The rainfall in the first hours was not accompanied by significant snowpack runoff (Fig. 3). This means that liquid water was stored in the snow cover by capillary suction and refreezing inside the snowpack. Refreezing was especially occurring at high altitude and at stations in Glarner Alpen, given the high cold content of those snow covers at the onset of rain (Table 1). Note that for typical snowpack conditions present at the onset of the rainfall, the amount of rain water needed to warm the snowpack to $0^{\circ} \mathrm{C}$ is in the order of $5 \mathrm{~mm}$ for the typical cold contents reported in Table 1. For this event, this is less than $10 \%$ of the total rainfall amounts. In the model, snowpack runoff started approximately $4-6 \mathrm{~h}$ after the onset of rain, depending on snow depth (Table 1). The amount of snow melt during the rainfall period was rather small compared to the rainfall amounts. Table 1 shows that the total amount of snow melt during the event was almost twice as large in Glarner Alpen as in Bernese Oberland, although this is partly caused by the lower average altitude of the stations in the Glarner Alpen and the exact values are strongly dependent on the choice of period. We can see that the average snowpack runoff curve is getting steeper during the rain episode and eventually becomes steeper than the rain curve (Fig. 3). After the rain stopped, snow melt continued due to the sensible heat flux provided by the increased air temperature. The snow melt exhibited a clear daily cycle on 11 and 12 October (Fig. 3), with a peak in the afternoon hours, associated with a high short-wave radiation input and a high air temperature.

To verify the snowpack simulations, the RMSE of measured and modelled snow height was calculated for the period 9 October, 18:00 UTC-11 October, 00:00 UTC (Table 1). Although snow water equivalent would be the preferred way to validate the simulations, as it better reflects the processes of snow melt, rainfall and liquid water flow than snow height, this is not possible due to the lack of validation data. However, measured snow height is generally considered an adequate estimate of snow water equivalent in physics-based models (Sturm et al., 2010). Because the simulations were forced by measured snow height, a high agreement between measured and modelled snow height is present for the ac-

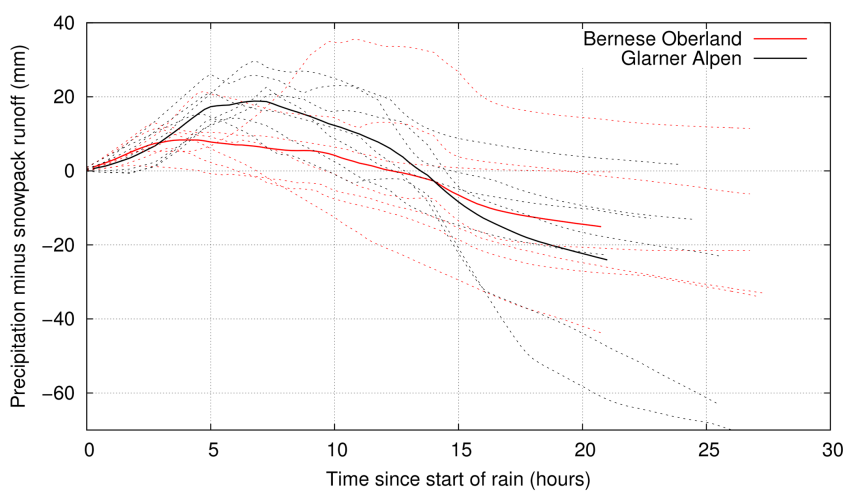

Figure 4. Cumulative rainfall minus cumulative modelled snowpack runoff during the event, starting at the onset of rain for each individual station (dashed lines) and for area averages (solid lines).

cumulation phase. By focusing solely on the ROS period itself, the RMSE values are indicative for the melt phase only. Most stations have an RMSE value below $5 \mathrm{~cm}$, indicating a satisfying agreement between measured and modelled snow height in the melt phase. The largest discrepancy is found for the highest station in the study, where the snow height is overestimated with an RMSE value of $18 \mathrm{~cm}$. Interestingly, the snow height is generally overestimated in the Bernese Oberland, whereas the opposite is found for the Glarner Alpen. Main reasons for this discrepancy may be an underestimation or overestimation, respectively, of snow melt, or an overestimation or underestimation, respectively, of new snow density and thus snow water equivalent.

In Fig. 4, the cumulative difference between rainfall and snowpack runoff is shown, starting from the onset of rain at the individual stations. When the curve is increasing, precipitation amounts exceed snowpack runoff, denoting storage of liquid water in the snowpack. A decreasing curve shows that the snowpack runoff is exceeding precipitation. The model results suggest that the snow cover was storing liquid water after the onset of the rainfall at all stations, dampening the effect of rain in the first few hours of the event. The initially dry and cold snow cover used the latent heat from refreezing rain water to get isothermal and also rain water was stored additionally in the snow cover by capillary suction. The shallow snow cover at the stations in the Bernese Oberland could retain less water than the deeper snow cover at the stations in Glarner Alpen. Furthermore, the tipping point where a net storage of liquid water in the snow cover changed into a net release of liquid water from the snow cover was reached earlier in Bernese Oberland $(4 \mathrm{~h})$ than in Glarner Alpen $(7 \mathrm{~h})$. Table 1 shows the time needed before cumulative snowpack runoff exceeded cumulative rainfall, which is generally shorter in Bernese Oberland than in Glarner Alpen. However, it still took on average $11-13 \mathrm{~h}$ from the start of rainfall before the total snowpack runoff exceeded total rainfall. This shows that the dampening effect of the rainfall by 


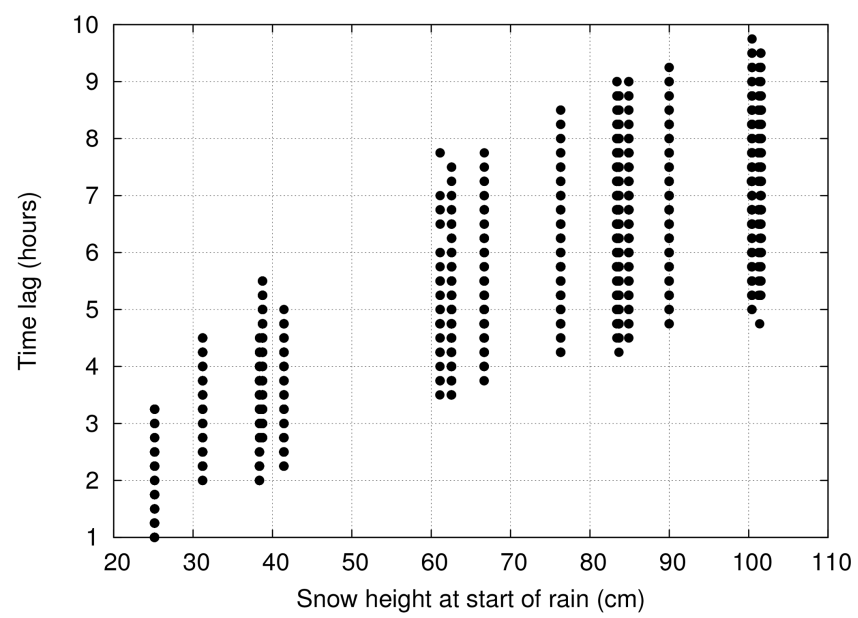

Figure 5. Time lag between the start of rain and the modelled start of snowpack runoff as a function of the snow height at the onset of rain for the ensemble simulations.

the snow cover was quite strong and persisted for several hours. Figure 4 also shows a wide spread between individual stations, related to variations in rainfall and snow melt rates. This motivated us to carry out the ensemble simulations that will be discussed later.

\subsection{Energy balance}

A net positive energy balance for the surface will first result in a heating of the snowpack (reducing the cold content), followed by melt. Table 2 shows the individual terms of the energy balance at the stations, expressed as $\mathrm{mm}$ w.e. melt potential as if the energy would be solely used for snow melt or freezing. The time period denoted as "Event" in Tables 1 and 2 is arbitrarily chosen to contain at least the complete rainfall, but longer or shorter time periods may have a significant effect on the relative contribution of the terms. A comparison with the amount of snow melt provided in Table 1 reveals that at all stations, most energy was used for snow melt. For stations with a high cold content, the net energy is partly used for heating of the snowpack. The contribution of net radiative energy, if not negative, and rain energy is fairly small. Most energy was delivered by heat release due to condensation during the ROS event and sensible heat. Mazurkiewicz et al. (2008) also found a strong contribution of latent heat to snow melt during ROS events. This is in contrast with typical clear sky spring snow melt situations, where the two terms often have opposite sign (Mott et al., 2013). Note that small discrepancies between total heat and snow melt (with more snow melt occurring than total heat provided) are due to small errors in the diagnosed energy balance as a result of the Dirichlet boundary condition at the upper and lower boundaries, as described before.

\section{Ensemble simulations}

Figure 5 shows the time lag between the onset of rain and the arrival of meltwater at the bottom of the snowpack as a function of snow height for the ensemble simulations. A general tendency of an increasing time lag with deeper snow covers is found, consistent with a longer travel time. However, the spread, caused by variations in rainfall and snow melt amounts, is very large. In Fig. 6, the snow height is divided by the time lag to get an approximation of the simulated velocity of the water movement in the snow cover. There is a clear dependency of the sum of rainfall and snow melt rate on flow velocity. Simulated water flow velocities range from $0.07 \mathrm{~m} \mathrm{~h}^{-1}$ for low rainfall and snow melt rates up to $0.20-0.25 \mathrm{~m} \mathrm{~h}^{-1}$ for the highest rates. These modelled values and the correlation with rainfall and snow melt rates match well with earlier published results: Jordan (1983) reports experimental values of $0.22 \mathrm{~m} \mathrm{~h}^{-1}$, and also shows that earlier studies found values ranging from 0.04 to $0.6 \mathrm{~m} \mathrm{~h}^{-1}$. The value of $0.22 \mathrm{~m} \mathrm{~h}^{-1}$ was determined for spring snow melt conditions, and is at the upper limit of what was simulated in this model study. The lower values in the simulations are likely associated with the state of the snow cover during this event. The relatively freshly fallen snow is generally fine grained, associated with a lower hydraulic conductivity than for spring snow. The upward trend with increasing rainfall and snow melt rates is associated with higher hydraulic conductivities as a result of a higher saturation inside the snow cover. Furthermore, in the presence of liquid water, wet snow metamorphism is rapid, resulting in grain growth, rounding, and consequently, an increase in hydraulic conductivity. In Singh et al. (1997), a very high velocity of $6 \mathrm{~m} \mathrm{~h}^{-1}$ was found for very high precipitation rates in a study with artificially created rainfall. In that study, it was concluded that the formation of efficient preferential flow paths (not considered in the SNOWPACK model) is likely contributing to this high average velocity.

\subsection{Regression analysis}

The regression analysis, as described by Eq. (2), was carried out to investigate the temporal evolution of the contribution of the different mechanisms in producing snowpack runoff. Figure 7a shows the regression coefficients of Eq. (2) for both the shallow and deep snow cover class as a function of cumulative period since the start of rain. In the shallow snow cover class, rain is correlated to snowpack runoff after $2 \mathrm{~h}$ already, whereas in the deep snow cover class, the first nonzero regression coefficient is found after $5 \mathrm{~h}$. This illustrates that the retardation between rainfall and snowpack runoff is dependent on snow depth. Furthermore, the coefficient for snow melt is higher in the shallow snow cover class than in the deep one in the early hours since the onset of snowpack runoff. The coefficient in the deep snow cover class is below 1.0 for several hours, denoting that $1.0 \mathrm{~mm}$ of additional 
Table 2. Energy balance at the stations for the period 9 October, 18:00 UTC-11 October, 00:00 UTC. The energy fluxes are expressed as an equivalent snow melt energy in mm w.e. for understanding the magnitude of the energy fluxes, although snow melt should not necessarily have occurred.

\begin{tabular}{|c|c|c|c|c|c|c|c|}
\hline Stn & $\begin{array}{l}\text { Altitude } \\
(\mathrm{m})\end{array}$ & $\begin{array}{c}\text { Rnet } \\
\text { (mm w.e.) }\end{array}$ & $\begin{array}{l}\text { Rain energy } \\
\text { (mm w.e.) }\end{array}$ & $\begin{array}{l}\text { Latent heat flux } \\
\text { (mm w.e.) }\end{array}$ & $\begin{array}{l}\text { Sensible heat flux } \\
\text { (mm w.e.) }\end{array}$ & $\begin{array}{l}\text { Soil heat flux } \\
\text { (mm w.e.) }\end{array}$ & $\begin{array}{c}\text { Total energy } \\
\text { (mm w.e.) }\end{array}$ \\
\hline \multicolumn{8}{|c|}{ Bernese Oberland } \\
\hline FAE2 & 1970 & 1 & 5 & 8 & 9 & 6 & 28 \\
\hline ELS2 & 2140 & -1 & 4 & 10 & 12 & 5 & 30 \\
\hline MUN2 & 2210 & -3 & 1 & 17 & 24 & 4 & 44 \\
\hline $\mathrm{SCH} 2$ & 2360 & -3 & 4 & 4 & 8 & 1 & 14 \\
\hline TRU2 & 2480 & -2 & 6 & 6 & 15 & -1 & 24 \\
\hline BEL2 & 2556 & -5 & 1 & 1 & 3 & 1 & 1 \\
\hline GAN2 & 2717 & -6 & 1 & 3 & 6 & 0 & 4 \\
\hline average all & 2348 & -3 & 3 & 7 & 11 & 2 & 21 \\
\hline \multicolumn{8}{|c|}{ Glarner Alpen } \\
\hline GLA2 & 1630 & 2 & 6 & 5 & 8 & 11 & 31 \\
\hline ORT2 & 1830 & -0 & 6 & 30 & 37 & 12 & 85 \\
\hline $\mathrm{SCA} 2$ & 2030 & -1 & 6 & 18 & 38 & 6 & 69 \\
\hline ELM2 & 2050 & -1 & 3 & 7 & 7 & 6 & 22 \\
\hline TUM2 & 2195 & -0 & 3 & 4 & 13 & 11 & 32 \\
\hline SCA3 & 2330 & -4 & 3 & 12 & 13 & 1 & 25 \\
\hline MUT2 & 2474 & -6 & 1 & 5 & 8 & 1 & 10 \\
\hline average all & 2077 & -1 & 4 & 12 & 18 & 7 & 39 \\
\hline \multicolumn{8}{|c|}{ Verification station } \\
\hline WFJ & 2540 & -6 & 0 & 8 & 14 & 0 & 17 \\
\hline
\end{tabular}

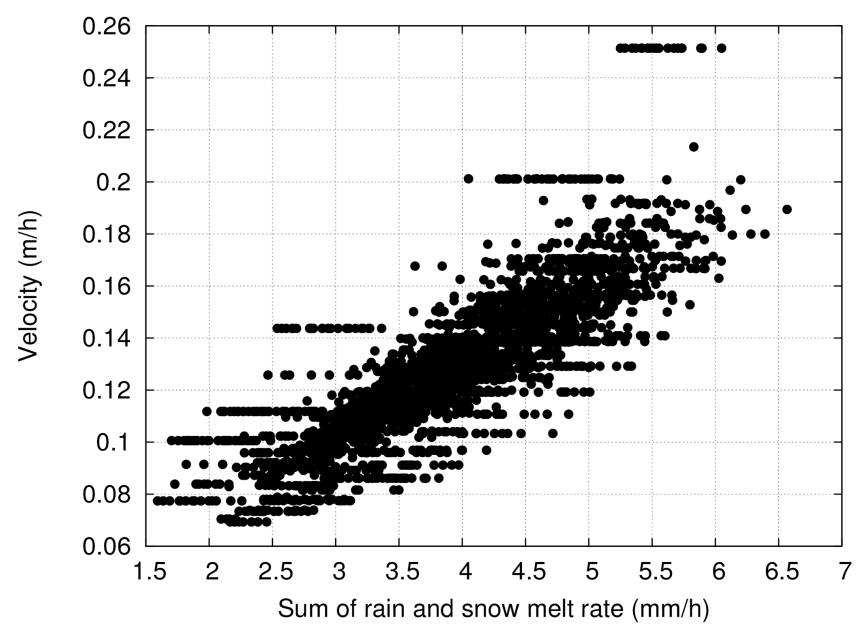

Figure 6. Simulated water velocity in the snow cover as a function of the sum of rain and snow melt in the first $5 \mathrm{~h}$ since the start of rain for the ensemble simulations.

snow melt would result in less than $1.0 \mathrm{~mm}$ extra snowpack runoff. This is caused by the long travel time needed by the liquid water arising from snow melt that occurred mostly near the surface. Only the part of the total snow melt near the base of the snowpack could have contributed to snowpack runoff in the first hours after the onset of rainfall.

After approximately $15 \mathrm{~h}$ from the start of rain, there is almost no difference in regression coefficient for snow melt and rain between the shallow and deep snow cover class. Then, the coefficient for rain is almost equal to 1.0, indicating that $1.0 \mathrm{~mm}$ of additional precipitation in this period would result in $1.0 \mathrm{~mm}$ extra snowpack runoff and the dampening effect of the snow cover has disappeared. Interestingly, the coefficient for snow melt is about 1.1, suggesting that there was approximately $10 \%$ more snowpack runoff from the snow cover than the amount of snow melt alone. We attribute this to the destruction of the snow matrix by snow melt, which reduced the storage capacity of the snowpack for liquid water. The intercept term clearly demonstrates that the deep snow covers had more storage capacity for meltwater, as the minimum is smaller than in the shallow snow cover class. This results in a longer delay between the onset of rain and the actual snowpack runoff. The intercept term is still negative after $24 \mathrm{~h}$, denoting that the effect of the storage capacity is noticeable over long periods.

In Fig. $7 b$, the regression coefficients are shown for cumulative periods starting at the onset of snowpack runoff. Expectedly, the intercept term changes sign: once snowpack runoff started, there was a contribution from the intercept. 

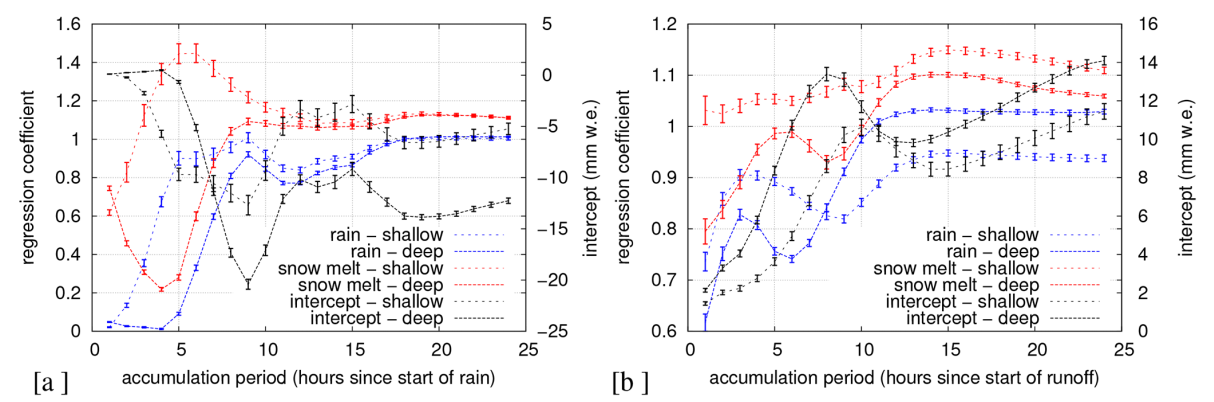

Figure 7. Regression coefficients as a function of cumulative period, since the start of rain (a) or start of snowpack runoff (b), for rain, snow melt and the intercept ( $\mathrm{mm}$ w.e.) for both the shallow and deep snow cover class.
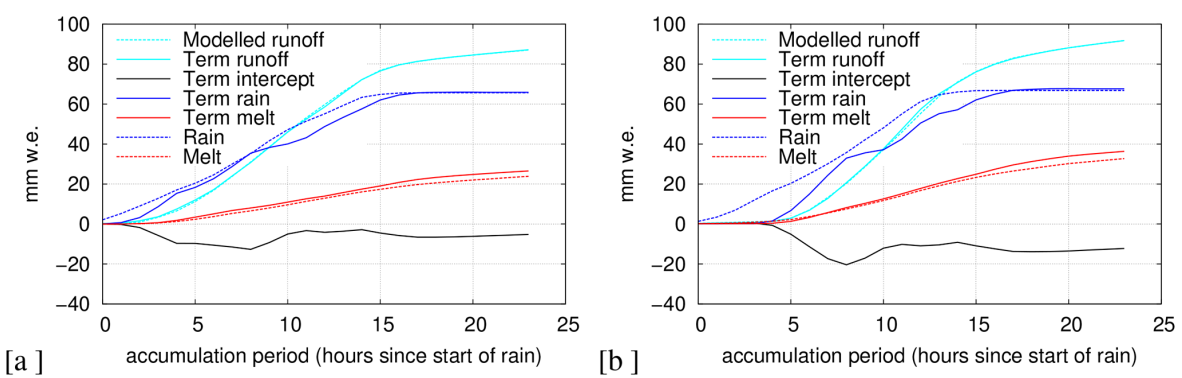

Figure 8. Modelled snowpack runoff, measured rainfall and modelled snow melt together with the terms of the linear regression for both the shallow (a) and the deep (b) snow cover class. Note that the blue, red and black solid lines sum up to the cyan line.

The intercept term is larger in the deep snow cover class than in the shallow one, indicating that in the simulations, deep snow covers produced more snowpack runoff, independent of snow melt or rainfall. This contribution consists of the snow melt and precipitation prior to the onset of snowpack runoff. Furthermore, settling may cause a reduction in storage capacity of the snow cover.

The stations in the shallow snow cover class have a higher coefficient for precipitation and snow melt in the short cumulative periods, denoting a stronger correlation of both variables with snowpack runoff shortly after the onset of runoff. We suggest that this is caused by short travel times through the snowpack in shallow snow covers. The difference with the deep snow cover class is decreasing with increasing time. After about $13 \mathrm{~h}$, the regression coefficients appear to remain fairly constant. Interestingly, for a deep snow cover, snow melt has a lower regression coefficient than for a shallow one while this is opposite for rain, for which we cannot offer an explanation. Another contrasting effect is that the regression coefficients for precipitation and snow melt show a larger increase with increasing cumulative period in the deep snow cover class than in the shallow one. This points towards a dynamic effect in the snowpack, likely associated with changing snowpack microstructure and associated hydraulic properties.

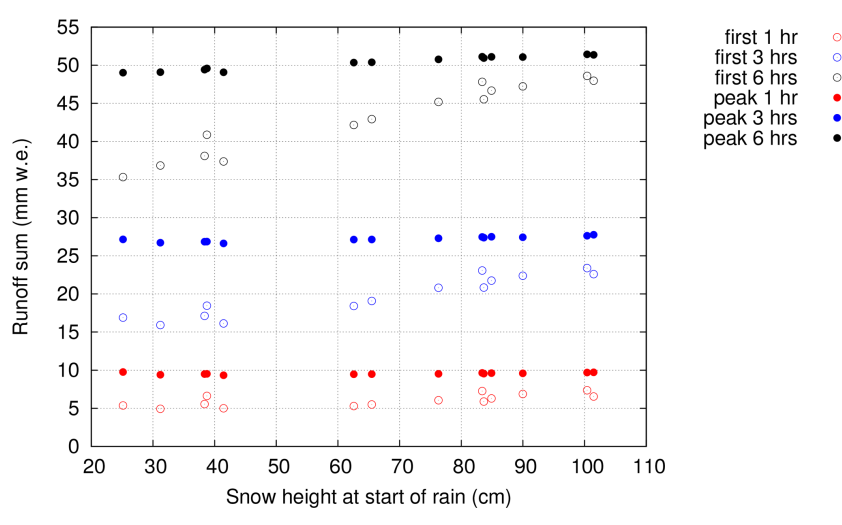

Figure 9. Average maximum cumulative snowpack runoff (denoted peak) and average cumulative snowpack runoff in the first hours after the start of snowpack runoff (denoted first), averaged over all ensemble simulations.

\subsection{Attribution}

In Fig. 8, the individual terms (precipitation, snow melt and intercept) and the sum (snowpack runoff) of the linear regression (Eq. 2) are shown, using the coefficients for both classes and the average rain and snow melt for each of the respective classes. Also drawn is the average modelled snowpack runoff. The almost perfect match between the modelled snowpack runoff and the sum of the linear regression terms shows that the regression analysis performs well. In both 


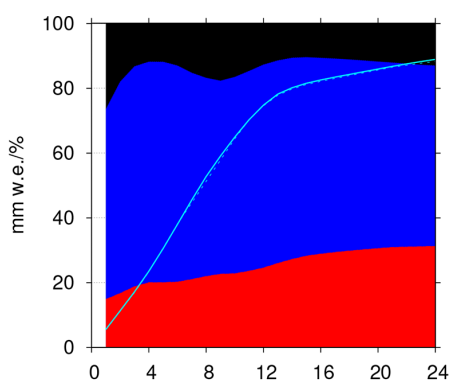

[a ] accumulation period (hours since start of runoff)

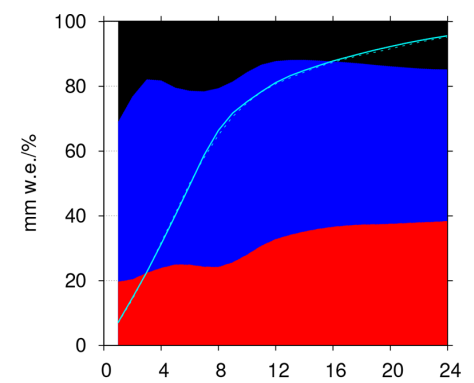

[b ] accumulation period (hours since start of runoff)

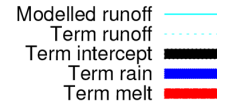

Term melt

Figure 10. Cumulative snowpack runoff (from model and from regression analysis) and the terms of the linear regression for both the shallow (a) and the deep (b) snow cover class.

classes, the modelled cumulative snowpack runoff curve is steeper than the cumulative rainfall curve and it is steeper in the deep snow cover class than in the shallow one. From the individual terms of the regression analysis, it can be derived that this is caused not only by the contribution of snow melt, but also by the decrease in the (negative) contribution of the snow storage, denoted by the intercept term. The results also suggest that the rainfall provided a stronger contribution in the deep snow cover class than in the shallow one, as expressed by the steeper curve of the rain term. The intercept term shows that there was a stronger dampening in the deep snow cover class than in the shallow one, although apparently it did not compensate the rainfall and snow melt contributions.

Figure 8 also shows that the time since the start of the rainfall after which the contribution of rainfall flattens out and the increase in snowpack runoff decreases (around $80 \mathrm{~mm}$ w.e.) lies for both snow depth classes around $16 \mathrm{~h}$. However, the modelled onset of snowpack runoff, and thus the onset of the individual terms in the regression analysis, was about $3 \mathrm{~h}$ later in the deep snow cover class than in the shallow one. This clearly illustrates that the model simulates a higher snowpack runoff rate in the deep snow cover class once snowpack runoff starts. To assess the relationship with snow cover depth, Fig. 9 shows the snowpack runoff sums in the first hours after the start of snowpack runoff and the maximum peak snowpack runoff sum over the first $24 \mathrm{~h}$ after the onset of rain, averaged over all 196 simulations per individual station (associated with a specific snow depth). In the first hours of modelled snowpack runoff, snowpack runoff rates show a clear increase with snow depth, whereas the trend is almost absent for the maximum peak snowpack runoff rates. The reason for the latter is that peak snowpack runoff is likely achieved in a kind of steady state situation when incoming rainfall and snow melt are in balance with snowpack runoff. The fact that this value is almost constant with snow depth is a consequence of the ensemble simulation setup, where all precipitation and melt scenarios are present for each station.

The simulations suggest that deep snow covers initially produced more snowpack runoff than shallow snow covers and that this effect is partly caused by hydraulic effects inside the snowpack and partly by higher snow melt amounts. In Fig. 10, the percentages of respectively intercept, snow melt and rainfall contributions to snowpack runoff are shown for increasing cumulative periods, as determined by the regression analysis. This confirms the earlier conclusions. The contribution of the storage is varying between 15 and $20 \%$ and is higher in the deep snow cover class. The contribution of snow melt is almost doubling from 15 and $20 \%$ to 30 and $38 \%$ between 1 and $24 \mathrm{~h}$ cumulative periods for the shallow and deep snow covers, respectively. The higher amount of snow melt experienced at the stations in the deeper snow cover class is likely unrelated to the deeper snow cover, whereas the higher contribution of the intercept term for the deeper snow cover class should be truly connected to the deeper snow cover.

\section{Discussion}

The response of the snowpack during a ROS event has been studied here using a physics-based snow cover model. The results depict how the SNOWPACK model simulates the influence of rainfall and snow melt on producing snowpack runoff and consequently, the conclusions drawn here are strongly dependent on a sufficient process representation in the SNOWPACK model. The comparison with snow lysimeter measurements at WFJ indicated that average velocity with which liquid water is routed through the snowpack in SNOWPACK was slightly underestimated, most likely due to neglecting preferential flow paths. This would imply that the time lag between the onset of rainfall and the onset of snowpack runoff is overestimated in the model. A preferential flow path formulation for physics-based snowpack models is not yet available and, to our knowledge, preferential flow paths are neglected in most physics-based models. It is difficult to speculate on the influence of preferential flow on the results presented here, in particular for contrasts between shallow and deep snow covers. However, the role of preferential flow in homogeneous layered snowpacks, as was the case in this particular event, may be limited. The snow at the onset of this ROS event had fallen during cold conditions in the 3 days 
prior to the event. We can thus assume that the initial snowpack was rather homogeneous with relatively small grains. In laboratory experiments, preferential flow was not observed for small grain sizes (Katsushima et al., 2013). From those experiments, the role of water ponding at strong transitions in snow properties between snow layers for the formation of preferential flow was also identified. These water accumulations may also trigger significant amounts of lateral flow, for example over ice layers inside the snowpack. However, it is unlikely that these inhomogeneities were present in the snow cover in this particular event.

Other discrepancies were found between measured and modelled snow height, which may be caused by underestimations or overestimations of snow settling and/or snow melt. However, typical RMSE for snow height was less than $5 \mathrm{~cm}$, which is around $2 \mathrm{~mm}$ w.e., dependent on snow density. Using the ensemble and regression analysis, the individual contributions of snow melt, rainfall and snow storage have been quantified by using melt scenarios from all stations. The higher snowpack runoff rates found in the simulations for deep snow covers were found to be not only dependent on snow melt, but also due to the effects of rainfall on deeper snow covers and the reaction of the snow storage. We therefore conclude that these discrepancies have only a small influence on the general validity of the results, even though the comparison of measured and modelled snow height suggested a consistent underestimation of snow melt in the Bernese Oberland and a consistent overestimation in the Glarner Alpen.

\section{Conclusions}

Model simulations of a ROS event in October 2011 for 14 meteorological stations in two regions of the Swiss Alps have shown that the snowpack runoff dynamics from the snow cover is strongly dependent on the snow depth at the onset of the rain. Deeper snow covers had more storage and absorbed all rain and meltwater in the first hours, whereas the modelled snowpack runoff from shallow snow covers reacted much more quickly to the onset of rainfall. The modelled time lag between the onset of rain and the onset of snowpack runoff ranged from 2.2 to $10 \mathrm{~h}$, depending on snow depth and cold content of the snowpack at the onset of rainfall, with an average around $4-5 \mathrm{~h}$. In this event, cumulative modelled snowpack runoff became higher than cumulative rainfall as a result of additional snow melt after on average 11-13 h.

An ensemble of simulations was carried out where meteorological and precipitation forcing conditions were interchanged between stations. It was found that the time lag between the onset of rainfall and snowpack runoff in the model study depends not only on snow height but also on the sum of rainfall and melt rates. Simulated flow rates of liquid water in the snowpack were smaller than observations in spring snow, which can be attributed to the structure of the snow- pack that consisted of small grains with a high suction and low hydraulic conductivity.

A regression analysis on the ensemble simulations has shown that deep snow covers generated more snowpack runoff, in the first hours after snowpack runoff started. The analyses suggested that this was caused by a higher release of liquid water from the storage in deep snow covers than in shallow ones. The quicker depletion of the storage in deep snow covers is partly driven by snowpack settling and partly by recession processes.

Note that these conclusions were derived for a ROS event during which the amount of rainfall largely exceeded the storage capacity of the snow, generating large amounts of snowpack runoff, even at locations with a deep snow cover. The effect of initial snow depth may be fundamentally different for ROS events in which rain falls on spring snow, where most settling has already occurred and liquid water is already present in the snowpack.

Given that the snow cover was deeper in Glarner Alpen than in Bernese Oberland, these differences in snowpack behaviour in terms of time lag between the onset of rain and the onset of snowpack runoff may have contributed to the differences found in streamflow discharge. In Bernese Oberland, streams reacted quickly on the onset of rain, whereas in Glarner Alpen, where the snow cover was thicker, flooding occurred mainly in the late afternoon of 10 October after most rainfall occurred (Badoux et al., 2013). On the other hand, the model results in this study have shown that once the snowpack produces runoff, the modelled snowpack runoff is higher in the deep snow cover class than in the shallow one. The validity of this conclusion depends on the adequacy of the representation of liquid water flow in the SNOWPACK model, as snow lysimeter measurements to support this result are lacking.

Acknowledgements. Part of this research was financed by the Swiss Federal Office for the Environment FOEN. Funding was also provided from the IRKIS project, supported by the Office for Forests and Natural Hazards of the Swiss Canton of Grisons (Chr. Wilhelm), the region of South Tyrol (Italy) and the community of Davos. We also would like to thank Jan Magnusson for his comments and suggestions for the analysis.

Edited by: H.-J. Hendricks Franssen

\section{References}

Badoux, A., Hofer, M., and Jonas, T. (Eds.): Hydrometeorologische Analyse des Hochwasser-ereignisses vom 10. Oktober 2011, Birmensdorf, Swiss Federal Institute for Forest, Snow and Landscape Research WSL; Davos, WSL-Institute for Snow and Avalanche Research SLF; Zürich, Federal Office of Meteorology and Climatology MeteoSwiss; Bern, geo7 geowissenschaftliches Büro; Bern, Federal Office for the Environment FOEN, in German, 2013. 
Calonne, N., Geindreau, C., Flin, F., Morin, S., Lesaffre, B., Rolland du Roscoat, S., and Charrier, P.: 3-D image-based numerical computations of snow permeability: links to specific surface area, density, and microstructural anisotropy, The Cryosphere, 6, 939-951, doi:10.5194/tc-6-939-2012, 2012.

Conway, H. and Raymond, C. F.: Snow stability during rain, J. Glaciol., 39, 635-642, 1993.

Hirashima, H., Yamaguchi, S., Sato, A., and Lehning, M.: Numerical modeling of liquid water movement through layered snow based on new measurements of the water retention curve, Cold Reg. Sci. Technol., 64, 94-103, doi:10.1016/j.coldregions.2010.09.003, 2010.

Jordan, P.: Meltwater movement in a deep snowpack: 1. Field observations, Water Resour. Res., 19, 971-978, doi:10.1029/WR019i004p00971, 1983.

Katsushima, T., Yamaguchi, S., Kumakura, T., and Sato, A.: Experimental analysis of preferential flow in dry snowpack, Cold Reg. Sci. Technol., 85, 206-216, doi:10.1016/j.coldregions.2012.09.012, 2013.

Kattelmann, R.: Macropores in snowpacks of Sierra Nevada, Ann. Glaciol., 6, 272-273, 1985.

Lehning, M., Bartelt, P., Brown, B., Russi, T., Stöckli, U., and Zimmerli, M.: SNOWPACK calculations for avalanche warning based upon a new network of weather and snow stations, Cold Reg. Sci. and Technol., 30, 145-157, doi:10.1016/S0165232X(99)00022-1, 1999.

Lehning, M., Bartelt, P., Brown, B., Fierz, C., and Satyawali, P.: A physical SNOWPACK model for the Swiss avalanche warning Part II. Snow microstructure, Cold Reg. Sci. Technol., 35, 147-167, doi:10.1016/S0165-232X(02)00073-3, 2002a.

Lehning, M., Bartelt, P., Brown, B., and Fierz, C.: A physical SNOWPACK model for the Swiss avalanche warning Part III: Meteorological forcing, thin layer formation and evaluation, Cold Reg. Sci. Technol., 35, 169-184, doi:10.1016/S0165232X(02)00072-1, 2002b.

Marks, D., Kimball, J., Tingey, D., and Link, T.: The sensitivity of snowmelt processes to climate conditions and forest cover during rain-on-snow: a case study of the 1996 Pacific Northwest flood, Hydrol. Process., 12, 1569-1587, doi:10.1002/(SICI)10991085(199808/09)12:10/11<1569::AID-HYP682>3.0.CO;2-L, 1998.

Marks, D., Link, T., Winstral, A., and Garen, D.: Simulating snowmelt processes during rain-on-snow over a semi-arid mountain basin, Ann. Glaciol., 32, 195-202, doi:10.3189/172756401781819751, 2001.

Marsh, P.: Snowcover formation and melt: recent advances and future prospects, Hydrol. Process., 13, 2117-2134, doi:10.1002/(SICI)1099-1085(199910)13:14/15<2117::AIDHYP869>3.0.CO;2-9, 1999.

Marsh, P.: Encyclopedia of Hydrological Sciences., chap. 161: Water Flow Through Snow and Firn, 1-14, John Wiley \& Sons, Ltd, Chichester, England, doi:10.1002/0470848944.hsa167, 2006.
Marshall, H., Conway, H., and Rasmussen, L.: Snow densification during rain, Cold Reg. Sci. Technol., 30, 35-41, doi:10.1016/S0165-232X(99)00011-7, 1999.

Mazurkiewicz, A. B., Callery, D. G., and McDonnell, J. J.: Assessing the controls of the snow energy balance and water available for runoff in a rain-on-snow environment, J. Hydrol., 354, 1-14, doi:10.1016/j.jhydrol.2007.12.027, 2008.

MeteoSwiss: Documentation of MeteoSwiss Grid-Data Products, Daily Precipitation (final analysis): RhiresD, Tech. rep., Federal Office of Meteorology and Climatology MeteoSwiss, Zürich, Switzerland, 2013.

Mott, R., Gromke, C., Grünewald, T., and Lehning, M.: Relative importance of advective heat transport and boundary layer decoupling in the melt dynamics of a patchy snow cover, Adv. Water Resour., 55, 88-97, doi:10.1016/j.advwatres.2012.03.001, 2013.

Omstedt, A.: A coupled one-dimensional sea ice-ocean model applied to a semi-enclosed basin, Tellus A, 42, 568-582, doi:10.1034/j.1600-0870.1990.t01-3-00007.x, 1990.

Pradhanang, S. M., Frei, A., Zion, M., Schneiderman, E. M., Steenhuis, T. S., and Pierson, D.: Rain-on-snow runoff events in New York, Hydrol. Process., 27, 3035-3049, doi:10.1002/hyp.9864, 2013.

Rössler, O., Froidevaux, P., Börst, U., Rickli, R., Martius, O., and Weingartner, R.: Retrospective analysis of a nonforecasted rainon-snow flood in the Alps - a matter of model limitations or unpredictable nature?, Hydrol. Earth Syst. Sci., 18, 2265-2285, doi:10.5194/hess-18-2265-2014, 2014.

Schmucki, E., Marty, C., Fierz, C., and Lehning, M.: Evaluation of modelled snow depth and snow water equivalent at three contrasting sites in Switzerland using SNOWPACK simulations driven by different meteorological data input, Cold Reg. Sci. Technol., 99, 27-37, doi:10.1016/j.coldregions.2013.12.004, 2014.

Singh, P., Spitzbart, G., Hübl, H., and Weinmeister, H.: Hydrological response of snowpack under rain-on-snow events: a field study, J. Hydrol., 202, 1-20, doi:10.1016/S0022-1694(97)000048, 1997.

Sturm, M., Taras, B., Liston, G. E., Derksen, C., Jonas, T., and Lea, J.: Estimating Snow Water Equivalent Using Snow Depth Data and Climate Classes, J. Hydrometeor, 11, 1380-1394, doi:10.1175/2010JHM1202.1, 2010.

Sui, J. and Koehler, G.: Rain-on-snow induced flood events in Southern Germany, J. Hydrol., 252, 205-220, doi:10.1016/S0022-1694(01)00460-7, 2001.

Wever, N., Fierz, C., Mitterer, C., Hirashima, H., and Lehning, M.: Solving Richards Equation for snow improves snowpack meltwater runoff estimations in detailed multi-layer snowpack model, The Cryosphere, 8, 257-274, doi:10.5194/tc-8-257-2014, 2014.

Yamaguchi, S., Katsushima, T., Sato, A., and Kumakura, T.: Water retention curve of snow with different grain sizes, Cold Reg. Sci. Technol., 64, 87-93, doi:10.1016/j.coldregions.2010.05.008, 2010. 